\title{
Political implications of the Trinity: Two approaches
}

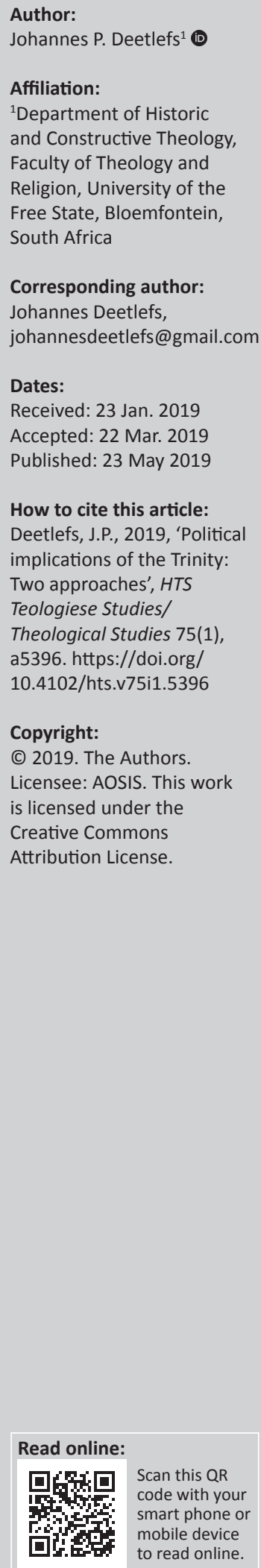

The political nature of God-images is an indisputable fact. Changes in God-images are often followed by changes in political structures within societies. Radical monotheism, where God is perceived as a solitary single person, has often in the past been employed for the justification of authoritarianism and hierarchy. The 20th-century trinitarian renaissance has emphasised the relationality of the Divine. This new awareness of the doctrine of the Trinity and the move from a substance ontology to a relational ontology have initiated a number of studies, which concentrate on the relevance of the Trinity for human existence, including politics. This move has been questioned by some scholars, who caution that the differences between the divine and human persons are just too significant for humans to be able to imitate the Trinity. These scholars suggest that participation in Christ is a more appropriate avenue to be followed. The position taken in this study is that both imitation and participation are valid options with biblical justification, and that the dichotomy, where one is set against the other, should be avoided.

Keywords: God-image; Imitation; Participation; Perichoresis; Person; Politics; Relationality; Trinitarian; Trinity.

\section{Introduction}

The 20th century has witnessed a revival of interest in the doctrine of the Trinity and its significance for human life (cf. Phan 2011:13; Bray 2006:20; Thompson 1997:11; Venter 2011:3-4). The 'renaissance' of trinitarian theology, accompanied by a turn from a substantial to a relational ontology, has led to a new appreciation of the distinctions within God's being. This development has led to a fresh appreciation of the complex nature of the Divine and a sense that 'ultimate reality is to be understood as relational' (Venter 2014:2).

The turn from a substantial to a relational ontology has further stimulated renewed consideration of the impact of a trinitarian concept of God on the political structures within societies. In his insightful work, Nicholls (1989) documents how Christian conceptions of God during different stages of society have been influenced by political experience and, in turn, have influenced political concepts as well. A close association exists between images of God and concepts of political authority (Venter 2008:148). It has been argued that radical monotheism, where the unity of God is so emphasised that the triune nature of the Divine is neglected, advances monolithic (authoritarian) political systems, while the Trinity, with its emphasis on inclusiveness and equality, advances democracy and political pluralism (Moltmann 1981:193, 2010:89; Nicholls 1989:234-235; Parker 1980:173). Although there is agreement among scholars about the importance of the doctrine of the Trinity for human existence, including politics, there are differences about the practical implications of how the Trinity should impact society. Some scholars argue that Christian communities should be a reflection of the triune nature of God (Boff 1988:119-120; Moltmann 1981:199), while others argue against any notion of applying trinitarian doctrine to human existence (Kilby 2014; Tanner 2004, 2010, 2015). This article will consider two approaches to the political implications of the Trinity, and suggest a third approach that negotiates both these approaches.

\section{Background: Turn to Social Trinity}

An important outcome of the renewal of trinitarian theology is the turn to a Social Trinity. In social trinitarianism, the personhood of the Trinity is located in the three hypostases and not in the one substance. Social trinitarians argue that the proper locus of divine personhood is the diversity within God - the three hypostases. In this view, God is not a solitary single person but three

Note: The collection entitled 'God as One', sub-edited by Erna Oliver (University of South Africa) and Willem Oliver (University of South Africa).

This article is a reworked version of aspects from the PhD dissertation of the author, entitled 'God-images and politics: The contribution of trinitarian theology', University of the Free State, under the supervision of Prof. R. Venter. 
'persons' - Father, Son and Spirit - who together comprise the one true God (Plantinga, Thompson \& Lundberg 2010:131), a being in communion (Gunton 1997:9). Venter suggests that from the unity and plurality of God as Father, Son and Spirit flow two critically important insights: the relationality of being and that this relationality constitutes identity. 'God is Father, Son and Spirit, and Father, Son and Spirit are uniquely that because of their respective relationships' (Venter 2014:2). The emphasis on relationality as characteristic of the divine life opens up new possibilities for, and a better understanding of, trinitarian theology. One of the outcomes of this development is the articulation of a social analogy in order to answer the oneness or threeness question regarding the Trinity. Today, a number of contemporary theologians can be named who advocate a relational (social) Trinity (Boff 1988; Johnson 1992; LaCugna 1991; Moltmann 1981; Plantinga 1989; Volf 1998a, 1998b; Zizioulas 1985).

However, one should be careful not to regard 'person' in its modern sense as an individual substance. The trinitarian persons are unique and exist only in their relationships with one another (Moltmann 1991:171-172). Zizioulas distinguishes between person and individual, and emphasises the relational character of personhood (Zizioulas 1985:88). Applied to the persons of the Trinity, this means that each person exists in the light of the others and receives the fullness of eternal life from the others (Moltmann 1991:173-174).

The use of the term 'person' to refer to the three members of the Trinity has been the cause of much debate and misunderstanding. Originally, from its meaning as 'mask', the term was used to refer to the actors in a play. Later it became identified with the idea of a person as an individual. Kärkkäinen points out that neither the etymology of the word (mask) nor its modern meaning (individual) captures the 'distinction-in-unity' of the triune God very well (Kärkkäinen 2007:30). For this reason, both Barth (2004:355, 358-359) and Rahner (1997:73-74) were sceptical of the term. It is common knowledge that Augustine found the use of the word 'person' unsatisfactory and the only reason he continued its use was the lack of a more appropriate word. The idea of person as an isolated individual who can theoretically be detached from the world is problematic. Personhood cannot be separated from relation (Cunningham 1998:27). Moltmann describes the divine persons of the Trinity 'in their relationships to one another' and concludes that it 'is in these relationships that they are persons' who 'realize themselves in one another by virtue of selfsurrendering love' (Moltmann 1981:171-174).

Social trinitarians are sometimes accused of emphasising the plurality of the three hypostases in a way that undermines the unity of God (Holmes 2009:86-87, 2012:200). However, this is a very simplistic way of evaluating social trinitarianism. Social trinitarians confess only one God who eternally exists in three persons. Christianity has always been a monotheistic religion. The 'uncompromising monotheism of the faith of Israel' (Kärkkäinen 2007:3) is confirmed by the biblical witnesses - Old Testament and New Testament - which unanimously declare that there is only one God (Dt 6:4; Mk 12:29-30). Trinitarian theology is a unique form of monotheism in which the confession that there is only one God (against all forms of polytheism) is maintained and emphasised while, at the same time, the biblical revelation that this one God eternally exists in three persons - Father, Son and Holy Spirit (against all forms of modalism) - is confirmed. It takes seriously the biblical witness that there is only one true God (Dt 6:4; 1 Cor 8:6). It also fully accepts that Jesus and the Spirit, together with the Father, but also distinct from the Father, are truly God (Jn 20:28; Ac 5:3-4), and yet, that God remains one.

The social doctrine of the Trinity relates well to the concept of God in African theology. Ogbonnaya claims that in traditional African thought God cannot be one (alone) in the sense of singular, but is considered to be communal (Ogbonnaya 1994:20). Emphasis of communal life 'community, communalism, and participation' - is a distinguishing mark of African cultures (Ogbonnaya 1994:xvii-xviii). Unlike most Western cultures, community in African cultures is all-embracing and includes ancestors, spirits and other beings. Communities create a spiritual bond, not only with close family but also with people beyond the limits of distance, time and eternity. This communal life involves more than just encountering the physical world. It also includes the always existing spiritual ties to the community (Ogbonnaya 1994:7). Kombo asks, '[w]ould this [the African concept of God] amount to polytheism?', and answers ' $[n]$ ot at all because the Christian faith has always seen itself as monotheistic in the same way the Rabbinic thought of the second century did' (Kombo 2009:138).

\section{Trinity and politics}

Different approaches towards the question of the relevance of the doctrine of the Trinity for politics have surfaced. It is suggested by certain scholars (Boff 1988:119; Gunton 1997:78; LaCugna 1991:402) that the Trinity has practical relevance for human life and society, and may act as a model to be imitated. LaCugna, for example, emphasises that the doctrine of God has vast political implications, and it matters greatly whether the doctrine of God is trinitarian or unitarian' (LaCugna 1991:394). Moltmann is equally convinced that societies reflect their fundamental theological outlook, including their basic understanding of God, in the ways in which they organise themselves politically (Moltmann 1981:192-200). Other theologians (Holmes 2009, 2012; Kilby 2014; Tanner 2004, 2007, 2010, 2012, 2015) have voiced concerns about the claims being made for the alleged political implications of the doctrine of the Trinity, which they regard as pure speculation.

Tanner, for instance, criticises the ways in which the Trinity has been utilised as a model for politics and rejects any notion of an imitation of the Trinity (Tanner 2007:129-145). Likewise, Kilby argues that the doctrine of the Trinity is a second-order proposition for a way to read the Bible and to pray, and does 
not give a picture of what God is like within Godself, and is therefore meaningless for politics (Kilby 2014:77, 82). The question, then, is: 'In what way (if any) can the trinitarian confession be related to the political dimension of society?' To answer the question, the two contrasting approaches above will be briefly considered as they are presented in the theologies of Jürgen Moltmann and Kathryn Tanner, respectively.

References to politics here include any structures of human communities characterised by the use of power for the ordering of relationships (Bell 2004:423), and not only in its formal sense of referring to the ruling government of a nation. In the social relationships between groups of people (civic as well as ecclesial), the undercurrent of power plays an important role. It often happens that those who have power use (and sometimes abuse) it to influence and manipulate the powerless and vulnerable. Taking into account the dialectical relationship between theology and politics, it is important that we consider the ways in which perceived concepts of God may impact politics.

\section{Imitation of the Trinity}

The renowned German theologian, Jürgen Moltmann, argues in favour of the imitation of the Trinity in the structuring of social and political spaces. Moltmann is critical of a radical concept of monotheism in which the reality of the plurality within the divine life is neglected. Such an understanding of monotheism, he claims, has been employed for the justification of monolithic and authoritarian political structures (Moltmann 1981:192-200, 2010:85-100):

The notion that the one God in heaven has to have the one ruler on earth as his correspondence, and that the divine universal sovereignty has to be matched by political rule over the earth, is age-old political theology. (p. 87)

According to him, civil as well as ecclesiastical, totalitarianism is often the result of erroneous 'political and clerical monotheism' caused by the disintegration of the doctrine of the Trinity into 'abstract monotheism'. This move enhances monarchical and authoritarian structures: 'one God - one emperor - one church - one empire' (Moltmann 1981:195):

As long as the unity of the triune God is perceived as monadically or subjectivistically, and not in trinitarian terms, the whole cohesion of a religious legitimation of political sovereignty continues to exist. It is only when the doctrine of the Trinity vanquishes the monotheistic notion of the great universal monarch in heaven, and his divine patriarchs in the world, that earthly rulers, dictators and tyrants cease to find any justifying religious archetypes any more. (p. 197)

The alternative, Moltmann argues, is a robust trinitarian concept of the Divine. Moltmann (1981) emphasises that:

... the Trinity corresponds to a community in which people are defined through their relations with one another and in their significance for one another, not in opposition to one another, in terms of power and possessions. (p. 198)
He claims that the way in which humans reflect the image of God is not in their individuality, but in their relations with one another. It is not 'human individuality' as much as 'human sociality' that reflects God's image in humans (Moltmann 1981:199). The relations between the divine persons correspond to the relations between human persons, not univocally or directly, but analogically (Van Wyk 2017:100).

Moltmann emphasises the sociality of God. God is 'love' exactly because God is not solitary, but a 'unique divine community through their self-giving to each other'. Father, Son and Holy Spirit are united through eternal love, and 'their unity consists in their oneness with each other' (Moltmann 2010:151). In this perichoretic unity of the triune God, 'person' is defined in relational terms, or as Moltmann describes it, 'a perichoretic concept of person' (Moltmann 2010:156). Moltmann rejects the concept of persons as 'individuals' and insists that it is only in their mutual relations that their personhood exists. 'Being a person in this respect means existing-in-relationship' (Moltmann 1981:172). Through their selfless love, each person comes to himself in the others. Moltmann emphasises that this unity should not be perceived as a closed unity, but is open so that others, even from a different kind, may be included (Moltmann 2010:156). The overflowing love between the Father and the Son through the Holy Spirit creates a space for human beings to be taken up into the 'divine embrace' (Moltmann 2010:157). This is the meaning of Jesus' high priestly prayer: 'As you, Father, are in me and I am in you, may they also be in us' (Jn 17:21). In the words of Moltmann (1981):

The union of the divine Trinity is open for the uniting of the whole creation with itself and in itself. So the unity of the Trinity is not merely a theological term; at heart it is a soteriological one as well. (p. 96)

The Trinity functions as a model for an egalitarian, as opposed to a monarchical, society in the way that the unity of the Trinity is not that of an omnipotent monarch, but of the Father with the Son who was delivered and crucified, and with the Spirit who renews heaven and earth (Moltmann 1981:197). God's glory is not reflected in the triumphs of the mighty, but in the crucified Christ. The 'life-giving Spirit' does not proceed from absolute lordship and power, but from the Father of the crucified Christ. God is not identified by almighty power, but by love (Moltmann 1981:197-198). The features of trinitarian fellowship are mutual self-giving love, equality of persons and infinite generosity (Van Wyk 2017:105). When societies imitate the triune life of God, both human individual rights and the rights of society are acknowledged, creating 'a truly “humane" society' (Moltmann 1981:200).

\section{Participation in Christ}

A theologian who has expressed serious concerns about claims made for the political significance of the Trinity is Kathryn Tanner of Yale Divinity School. Tanner opines that, as Christianity is not only a set of abstract beliefs but also a way of living, all theology is political and could therefore 
influence the ordering of social and political relations. Belief that the world was created by a 'loving God', and that humans should reflect this love, gives meaning to 'love-filled relations with others' (Tanner 2004:319-321). This is also clear from the incorporation of political images for theological purposes, such as talk of God as king, which 'may be a way of making kings into God'. She finds it, therefore, not strange that theologians would turn to the Trinity - as the distinguishing doctrine of Christianity - to defend specific political structures. 'The relations between one substance and three persons in the Trinity can be unpacked in terms of a relation between a community and its members' (Tanner 2004:321).

However, Tanner rejects the idea that the Trinity is 'the best indicator of the proper relationship between individuals and their community'. She objects to, what she regards as 'inflated claims' being made for the Trinity, and argues that the political potential of the Trinity is mostly overstated (Tanner 2007:129). She also rejects the argument that monotheism promotes monolithic identities with authoritarian forms of government, while the Trinity advances egalitarian or democratic political structures. What advocates of such a view fail to recognise, Tanner argues, is the complexities of such claims in view of their 'fluidity of sense' and 'the possible variety of political purposes' they may serve. She points out that trinitarianism has not always in the past been associated with egalitarian politics (Tanner 2012:371-372).

Tanner also emphasises the 'ambiguous socio-political potential' of trinitarian theology. The divine persons are equal to one another 'because in some very strong sense they are the same', something that can never be said about human persons (Tanner 2012:372-373). The very order of the three divine persons (the Father is always first, the Son second and the Spirit third), she argues, more clearly promotes a human hierarchy than an egalitarian society. This is further underlined when one turns to the economic Trinity, where the relation of Jesus to the Father is much more 'subordinationalist'. Add to this the gendered imagery used to refer to the members of the Trinity and you are faced with complications (Tanner 2012:373). She therefore concludes that 'Trinitarianism can be every bit as socially and politically dangerous as monotheism' (Tanner 2012:375).

Tanner cautions that the similarities between human and divine persons do not weigh up to the differences between them and tersely remarks that 'God is not us' (Tanner 2012:378). Much of what is said of the Trinity is simply not directly applicable to humans. This poses difficulties for any movement from a discussion of God to human relationships. She emphasises that humans do not fully understand what the (metaphorical) language that they are obliged to use to speak of the Trinity really means. Given the mystery of the Trinity, how can one clearly understand what the Trinity is saying about human relations? Who can understand in what sense the persons of the Trinity are equal to one another? Or, in what sense they are one, or distinct from one another?
As humans cannot comprehend the Trinity fully, how can the Trinity help them to better understand human relationships, which, she points out, are also extremely complicated? For human societies to be able to reflect the relations of the trinitarian persons, she argues, humans will have to discontinue to be human. Divine persons are relational in a sense that human persons can never be. The relationship between the divine persons is such that they know each other fully, as each person fully dwells within the others and is simultaneously fully indwelt by the others, something that is impossible for human beings to imitate. It is just humanly impossible for human beings to know one another in this sense - human knowledge of one another is always incomplete (Tanner 2012:378-382). Tanner insists that it is impossible to bridge the gap between the Trinity and sinful humanity, because 'unlike the peaceful and perfectly loving mutuality of the Trinity, human society is full of suffering, conflict and sin' (Tanner 2012:381).

As alternative, Tanner offers her own suggestions for the way in which societies and politics should be influenced by theology (Tanner 2012:382-386). Instead of looking at the Trinity as a model for human relations, she points to Christology as a more appropriate avenue (Tanner 2012:382). As the second person of the Trinity in his human life is the only real image of God, participation in the life of Christ is the only way to reflect the image of God. It is only through being formed to the image of the second person of the Trinity that humans can image God (Tanner 2015:53). For Tanner (2010), everything that humans become, whether in their private lives or in relation to others within society, is only possible through their relationship with Christ:

Christ is the key ... to human nature, and to the sort of grace human nature was made to enjoy. But Christ is also the key ... to the trinity and its significance for us. Christ is the key ... because of the peculiar character of the human life he leads. Because he is the Word, Jesus Christ displays in his human life the relationships that the Word has to the other members of the trinity; as a human being he leads, in short, a trinitarian way of life. (p. 140)

Humans should reflect the image of God, not as a result of their imitation of the divine persons, but on account of their being in Christ and through him participating in the life of God (Tanner 2010:140). In this way, 'God becomes part of us' (Tanner 2015:63). We must not think of the second person of the Trinity as just our example to imitate, but as 'our entryway, our point of access into' the trinitarian life (Tanner 2010:142). In the incarnation, humanity and divinity are joined together into one. Therefore, the Trinity is not lowered to the human level to be imitated, but offers humanity the hope of one day being raised up to its level, not through imitating the Trinity, but by being taken up into the divine life itself. 'Jesus' way of life towards other people as we share in it is the trinitarian form of human social life' (Tanner 2012:383).

It is only in the second person of the Trinity that one can properly speak of the image of God (Heb 1:3), and this image is only displayed in the human life of Christ. It is only through 
participation in the life of the second person of the Trinity that humans become the image of God (Tanner 2015:59). Jesus' life in the economy of salvation does not only display the sort of relations humans have with the Father and the Spirit, but also how human relations with other people are worked out through their relations with the divine persons. When humans are incorporated within the trinitarian life through their relationship with Christ, 'all enter at the same point ... [and] ... become identified with the same Trinitarian person' - Jesus Christ - not as 'different people ... spread out across the Trinity to take on its pattern, ... but one in Christ, moving with the second person in his movement within the Trinity'. It is not the Trinity but the one divine Son and the one divine Spirit that determine our unity as a human community (Tanner 2012:384).

Tanner makes her position clear. The Trinity does not provide a model after which human societies should be emulated. Instead, by being joined to Christ, in whom divinity and humanity are united, humans are incorporated into the life of the Trinity and thus changed into the image of Christ (Tanner 2012:382):

Humans do not attain the heights of Trinitarian relations by reproducing them in and of themselves, by mimicking them, in other words, but by being taken up into them as the very creatures they are. (p. 383)

\section{Inescapable political nature of the Trinity}

The political consequences of radical monotheism have been described by Moltmann as the justification of the political rule of one ruler on earth by the universal sovereignty of the one God who rules in heaven (Moltmann 2010:87). According to him, the monotheistic reason for political power always leads to imperialism, where the 'imperator' rules over all while he himself is not ruled by anyone (Moltmann 2010:88). When Emperor Constantine declared Christianity the official religion of his empire, it was the image of the one heavenly monarch that he employed to justify his monarchy. Constantine's view was that of the one monarch in heaven, with himself as the earthly representative of a strictly monotheistic God - one God, one Logos, one emperor. As Fiddes (2000) aptly remarks:

The Logos rules over the universe and fights spiritual battles against demons and the hosts of darkness; Constantine rules over the earth and fights with the sword against the enemies of truth. (p. 64)

In contrast to radical monotheism, the fundamental principle of the Trinity, which is inclusiveness, supports diversity and plurality (Parker 1980:173). In trinitarian theology, God is 'understood to be a living communion of Three-in-One' (Irvin 2011:398). In this view, God is not perceived to be a solitary figure, but is eternally existing in three persons Father, Son, and Holy Spirit - who live in a mutual relationship of love, peace and harmony with each other. In trinitarian theology, God is 'a communion of equal persons who are mutually connected in love' (Van der Kooi \& Van den Brink
2017:109). In the community of the Trinity, where Father, Son and Holy Spirit are co-equal and co-dependent, and where one is not above the others, but the three persons are equal, each person glorifies the other persons (Irvin 2011:403). The Trinity is, therefore, a critique of the shapes of our social structures of exclusion and self-vindication, and speaks of inclusiveness, hospitality, embrace, diversity, generosity, community and self-giving (Venter 2011:15-16).

In view of the above, one may ask whether the Trinity would not create an environment where people are willing to make room for one another, and where peace, justice and dignity are promoted. Has the Trinity not perhaps been neglected for too long, and the possibilities of the ways in which a trinitarian God-image may positively influence communities not entertained? Although history does not confirm that monotheism always results in autocratic political authority or that a trinitarian concept of God always promotes egalitarian societies, it can be convincingly argued that the concept of the triune God would be more inclined to influence people to think of earthly structures more in terms of cooperation and community (Nicholls 1989:234-238). The form of life consistent with the Trinity is marked by justice and friendship, two necessary dimensions of human community (Parker 1980:179-180). The impact of a truly trinitarian concept of God is that the monarchical images of domination prevalent in society may be replaced with images that signify cooperation and participation. Such an image would provide the most satisfactory model from the standpoint of its political consequences' (Nicholls 1989:239-240).

The above discussion should, however, not diminish the truth that Christians worship only one God, and that Christianity is, therefore, a monotheistic religion. A social understanding of the Trinity should not rule out monotheism completely. That would lead to the heresy of tritheism. It must be clearly stated that it is a radical monotheism, where God is only portrayed as a single person with a single consciousness, to which social trinitarians object. The biblical witness to the relations of Father, Son and Spirit suggests that there are three distinct centres of consciousness within the Divine. Plantinga's claim that a 'person who extrapolated theologically from Hebrews, Paul, and John would naturally develop a social theory of the Trinity' is valid (Plantinga 1989:27).

The suggestion that humans are created in the image and likeness of God (Gn 1:26-27) has significant meaning for the question of the political influence of the doctrine of the Trinity. If humans are supposed to reflect - 'echo' (Gunton 1997:81) - the image of God in some way, then it should have an impact on social relations as well. LaCugna argues that 'the church is a sacrament of God's life' and should be 'a visible image that represents in concrete form the ineffable and invisible mystery of triune life' (LaCugna 1991:402). Gunton (1997:78) correctly states that the church should be 'a temporal echo of the eternal community that God is'. 
Boff (1988) views human societies as pointing towards the mystery of the Trinity, which he sees as 'the archetype' of human societies in which the communion of persons:

... lays the foundation for a society of brothers and sisters, of equals, in which dialogue and consensus are the basic constituents of living together in both the world and the church. (p. 120)

When humans imitate the Trinity in their personal as well as social lives, it holds the promise to impact societies positively.

A trinitarian image of God has significant consequences for post-colonial societies. The image of the persons of the Trinity, making space for one another in a relationship of equality and harmony, has the potential to promote societies that 'resolutely resist new temptations to exercise mastery over others' (Brett 2008:182). The fact that human beings are created in the image of the triune God rules out the mastering of certain individuals or groups over others. The widespread conviction of European racial superiority over the indigenous peoples of developing countries (such as Africa and Australia) allowed for the subjection of these people to slavery (Brett 2008:10). It was accepted that 'the higher order should rule over the lower order' even if it required the use of force (Brett 2008:13). The colonisers argued that it was their duty to bring 'civilisation' to the indigenous peoples and to subject their countries to European rulership. Much of the inequalities within societies are caused by the perception that some people are superior to others and, therefore, have to make decisions on their behalf, resulting in tension and resentment among those who are regarded as inferior. However, if humans are created in the image of God, all humans are equal and no one should be regarded as superior to the others. To quote Fiddes (2000) again:

The Christian idea of the Trinity has the potential for challenging and undermining this domination of the One. It forbids us from conceiving of God as the absolute individual, the solitary Father, the supreme Judge who provides support to a powerful human individual in his image. (p. 66)

However, Tanner's warning against 'inflated claims' made for the political potential of the Trinity is valid, and scholars should guard against any form of projection of their own ideals for society onto the image of the Trinity (Tanner 2007:129). Notwithstanding the (sometimes valid) concerns raised against imitation of the Trinity, Volf has convincingly argued that although humans cannot copy God in all respects, it does not mean that they cannot copy God at all. Somewhere between the extremes of copying God in all respects and not copying God at all, Volf reminds us, 'lies the widely open space of human responsibility which consists in "copying God in some respects"' (Volf 1998b:405).

The question is how humans should reflect the image of the Trinity. Theologians who reject imitation as a means of echoing the divine image cannot deny the fact that in Scripture Christians are exhorted to imitate God in various ways. The apostle Peter (1 Pt 1:16) quotes from the Old Testament (Lv 19:2 - 'You shall be holy, for I the Lord your God am holy') and exhorts Christians towards holy living. In 1 John (4:7-16), believers are told to imitate the love of God: 'Beloved, let us love one another ... for God is love'. Jesus commands his followers to love their enemies and pray for those who persecute them, because their heavenly Father treats good and evil persons with equal kindness (Mt 5:44-45). What is clear from the above discussion is that Christians are expected and encouraged to be a certain kind of person and to do certain kind of things through imitating God.

The word 'imitation' is an unhappy one and may create the perception that humans can imitate God in all respects. Gunton's choice of the word 'echo' (which, strictly speaking, refers to sound and not images) is a better choice (Gunton 1997:81). A reflection is not always very clear and it includes the possibility of reflecting the image of God in an imperfect and vague manner, almost like a person's faint reflection that is barely visible but yet visible enough for him or her to be identified. Because of the dissimilarities between the divine and human persons (Kilby 2014:75), the human reflection of the Trinity is not perfect but distorted in many ways. Because humans are creatures, they can reflect the image of God only in a creaturely manner (Volf 1998a:199). In this regard, the warning that 'God alone is God' (Peters 1993:186) must be heeded. At the same time, it must be insisted that as persons created in the image of God, humans are expected - and enabled - to reflect the divine persons in at least some ways. Although words such as 'person' and 'communion' cannot in a univocal sense mean the same when applied to the church as when they refer to the Trinity, they should be understood as 'analogous to them' (Volf 1998a:199).

It must further be granted that Scripture also clearly indicates that something happens to believers- not as the result of their own deed, but as the result of the work of God (the Holy Spirit) in their lives. Paul can encourage believers to cheerfully suffer all kinds of hardships because 'all things work together for good' and are aimed at the conformation of believers 'to the image' of the Son ( $R$ m 8:28-29). The Corinthians are assured that while 'seeing the glory of the Lord ... [they] are being transformed to the same image from one degree of glory to another' (2 Cor 3:18). This transformation that Scripture speaks about is the result of the believer's participation in the life of the Trinity. Christ promised his disciples that he and the Father would 'come to them and make [their] home with them' (Jn 14:23), and John encourages believers that 'our fellowship is with the Father and with ... Jesus Christ' (1 Jn 1:3). This communion is the answer to Jesus' prayer:

As you, Father, are in me and I am in you, may they also be in us ... I in them and you in me, that they may become completely one. (Jn 17:21-23)

Scripture argues in favour of both an imitation of the divine persons on behalf of humans and the results in human lives of their being taken up into the very life of the Trinity and their participation in the life of God. The dichotomy between imitation of and participation in the life of the Trinity should 
therefore be resisted. Tanner is correct when she insists that imitation of the Trinity cannot be a human effort independent of the work of the Holy Spirit (Tanner 2015:63), but she is wrong to deny any form of imitation. It is true that what humans become is only possible through their relationship with Christ, but it is equally true that through Christ believers are incorporated into the very life of the triune God and experience the mutual love and joy that are displayed within the heart of the Trinity. It is through this communion with the Father, Son and Spirit that believers are enabled to 'echo' the divine persons. However, the limitations of such imitations must be acknowledged.

\section{Conclusion}

From the above discussion, it can be concluded that the Trinity has the potential to affect human social engagement, including the way in which societies are structured (Volf 1998b:406). Radical monotheistic images, with their notion of singularity and uniqueness, tend to create a perception of one person, or group of people, above and superior over others. The doctrine of the Trinity, with its language of inclusiveness, equality and unity in diversity, on the other hand, has the potential to foster inclusive communities where difference is not regarded as a threat, but rather welcomed and accepted. Scripture encourages both participation in the divine life and imitation of the divine persons.

Although some scholars view the Trinity as a model for human and social life, they realise that humans could never imitate the Trinity in all respects. Volf cautions against a too simplistic correspondence between the Trinity and ecclesial and political structures, and argues that we should not 'overestimate the influence of Trinitarian thinking on ecclesial and political reality' (Volf 1998a:194). What we can, and should, do is to reflect something of the harmony and selfgiving love between the persons of the Trinity, even though such a reflection will be vague and incomplete.

It can, therefore, be claimed that the image of the Trinity has relevance for human practical life, both personally and socially. Although it is an overstatement to imply that a trinitarian God-image, in contrast to a strictly monotheistic image, always promotes egalitarian and democratic political structures as opposed to hierarchical, monarchical and authoritarian structures, it cannot be denied that the trinitarian grammar 'of personhood, of relationality, and of love' (Venter 2011:9) is more conducive to a society where persons are considered as equals and are respected and welcomed rather than exploited or excluded. In contrast to the individualism of modernity, religiously supported by an image of the one God of radical monotheism, a trinitarian God-image emphasises the relational nature of both the Divine and reality. The trinitarian confession has analogically generated interpretative possibilities for understanding human flourishing through relationships of recognition and embrace of the other. This demonstrates the value of constructive theology for the continued relevance of religion in pluralistic and multicultural societies burdened by alienation, as experienced in South Africa and globally.

\section{Acknowledgements}

\section{Competing interests}

The author declares that he has no financial or personal relationship(s) that may have inappropriately influenced him in writing this article.

\section{References}

Barth, K., 2004 (1975), Church Dogmatics 1/1: The doctrine of the Word of God, Transl. G. W. Bromiley, T\&T Clark London.

Bell, D.M., 2004, 'State and civil society', in P. Scott \& W.T. Cavanaugh (eds.), The Blackwell companion to political theology, pp. 423-438, Blackwell Publishing, Malden.

Boff, L., 1988, Trinity and society, transl. P. Burns, Burns \& Oates, Tunbridge Wells.

Bray, G., 2006, 'The Trinity: Where do we go from here?', in A.T.B. McGowan (ed.), Always reforming: Explorations in systematic theology, pp. 19-40, Leicester, Apollos.

Brett, M.G., 2008, Decolonizing God: The Bible in the tides of empire, Sheffield Phoenix Press, Sheffield.

Cunningham, D.S., 1998, These three are one: The practice of Trinitarian theology, Blackwell Publishing, Oxford.

Fiddes, P.S., 2000, Participating in God: A pastoral doctrine of the Trinity, Westminster John Knox, Louisville.

Gunton, C.E., 1997, The promise of Trinitarian theology, 2nd edn., T\&T Clark, Edinburgh.

Holmes, S.R., 2009, 'Three versus one? Some problems of social Trinitarianism', Journal of Reformed Theology 3, 77-89. https://doi.org/10.1163/156973109X403732

Holmes, S.R., 2012, The quest for the Trinity: The doctrine of God in Scripture, history and Modernity, IVP Academic, Downers Grove.

Irvin, D.T., 2011, 'The Trinity and socio-political ethics', in P. Phan (ed.), The Cambridge companion to the Trinity, pp. 398-413, Cambridge University Press, Cambridge.

Johnson, E.A., 1992, She who is: The mystery of God in feminist theological discourse, Crossroad, New York.

Kärkkäinen, V-M., 2007, The Trinity: Global perspectives, Westminster John Knox, Louisville.

Kilby, K., 2014, 'Trinity, tradition, and politics', in C. Chamalet \& M. Vial (eds.), Recent developments in Trinitarian theology, pp. 73-86, Fortress Press, Minneapolis, MN.

Kombo, J., 2009, 'The Trinity in Africa', Journal of Reformed Theology 3, 125-143. https://doi.org/10.1163/156973109X448698

LaCugna, C.M., 1991, God for us: The Trinity and Christian life, HarperCollins, New York.

Moltmann, J., 1981, The Trinity and the kingdom: The doctrine of God, transl. M. Kohl, Harper \& Row, San Francisco, CA.

Moltmann, J., 1991, History and the triune God: Contributions to Trinitarian theology, transl. J. Bowden, SCM Press, London.

Moltmann, J., 2010, Sun of Righteousness, Arise! God's future for humanity and the earth, transl. M. Kohl, Fortress Press, Minneapolis, MN

Nicholls, D., 1989, Deity and domination: Images of God and the state in the nineteenth and twentieth centuries, Routledge, London.

Ogbonnaya, A.O., 1994, On communitarian divinity: An African interpretation of the Trinity, Paragon House, New York.

Parker, T.D., 1980, 'The Political meaning of the Doctrine of the Trinity: Some theses', The Journal of Religion 60(2), 165-184. https://doi.org/10.1086/486775

Peters, T., 1993, God as Trinity: Relationality and temporality in divine life, Westminster John Knox, Louisville, KY.

Phan, P.C., 2011, 'Developments of the doctrine of the Trinity', in P.C. Phan (ed.), The Cambridge companion to the Trinity, pp. 3-12, Cambridge, Cambridge University Press.

Plantinga, C. Jr., 1989, 'Social Trinity and tritheism', in R.J. Feenstra \& C. Plantinga, Jr. (eds.), Trinity, incarnation and atonement: Philosophical and theological essays, pp. 21-47, University of Notre Dame Press, Notre Dame.

Plantinga, R.J., Thompson, T.R. \& Lundberg, D., 2010, An introduction to Christian theology, Cambridge University Press, Cambridge.

Rahner, K., 1997 (1970), The Trinity, transl. J. Donceel, Crossroad, New York.

Tanner, K.E., 2004, 'Trinity', in P. Scott \& W.T. Cavanaugh (eds.), The Blackwell companion to political theology, pp. 319-332, Blackwell Publishing, Malden.

Tanner, K.E., 2007, 'Kingdom come: The Trinity and politics', The Princeton Seminary Bulletin 28(2), 129-145.

Tanner, K.E., 2010, Christ the key, Cambridge University Press, Cambridge. 
Tanner, K.E., 2012, 'Social Trinitarianism and its critics', in G. Maspero \& R.J. Wozniak (eds.), Rethinking Trinitarian theology: Disputed questions and contemporary issues in Trinitarian theology, pp. 368-386, T\&T Clark, London

Tanner, K.E., 2015, 'In the image of the invisible', in M. Welker \& W. Schweiker (eds.) Images of the Divine and cultural orientations: Jewish, Christian, and Islamic voices, pp. 51-65, Evangelische Verlagsanstalt, Leipzig.

Thompson, T.R., 1997, 'Trinitarianism today: Doctrinal renaissance, ethical relevance, social redolence', Calvin Theological Journal 32, 9-42.

Van der Kooi, C. \& Van den Brink, G., 2017, Christian Dogmatics: An introduction transl. R Bruinsma \& J.D. Bratt, Wm B Eerdmans, Grand Rapids, MI.

Van Wyk, T., 2017, 'Om vrylik asem te haal in die lewensruimte van die Trinitariese God: Jürgen Moltmann se bydrae tot ' $n$ Reformatoriese teologie van solidariteit', in Nadenke oor 500 jaar se Reformatoriese teologie, HTS Theological Studies/ Teologiese Studies, suppl. 11, 73(5), a4556:91-110, viewed 01 May 2018, from https://doi.org/10.4102/hts.v73i5.4556.
Venter, R., 2008, 'God images, ethical effects and the responsibility of Systematic Theology', Acta Theologica 2008(2), 146-164.

Venter, R., 2011, Speaking God today: The adventures of a rediscovered Trinitarian grammar, Inaugural lecture, University of the Free State, Bloemfontein.

Venter, R., 2014, 'The triune God and the relational turn: Implications for reconciliation in South Africa?', paper presented at the Tutu-Jonker Dialogue Series on Reconciliation, University of the Free State, Bloemfontein, 31st July.

Volf, M., 1998a, After our likeness: The church as the image of the Trinity, Wm B Eerdmans, Grand Rapids, MI.

Volf, M., 1998b, "'The Trinity is our social program": The doctrine of the Trinity and the shape of social engagement', Modern Theology 14(3), 403-423. https://doi. org/10.1111/1468-0025.00072

Zizioulas, J.D., 1985, Being as communion: Studies in personhood and the Church, St Vladimir's Seminary Press, Crestwood. 